\title{
antioxidants
}

ISSN 2076-3921

www.mdpi.com/journal/antioxidants

Article

\section{Bioactive Compounds and Antioxidant Activity in Different Grafted Varieties of Bell Pepper}

\section{Celia Chávez-Mendoza ${ }^{\dagger}$, Esteban Sanchez *, Ezequiel Muñoz-Marquez ${ }^{\dagger}$, Juan Pedro Sida-Arreola ${ }^{\dagger}$ and Maria Antonia Flores-Cordova ${ }^{\dagger}$}

Coordinación en Tecnología de Productos Hortofrutícolas y Lácteos Centro de Investigación en Alimentación y Desarrollo A C, Avenida Cuarta Sur No. 3820 Fraccionamiento Vencedores del Desierto. Cd. Delicias, Chihuahua C.P.33089, Mexico; E-Mails: celia.chavez@ciad.mx (C.C.-M.); emunoz@ciad.mx (E.M.-M.); johnvih@gmail.com (J.P.S.-A.);

mariflor_556@hotmail.com (M.A.F.-C.)

$\dagger$ These authors contributed equally to this work.

* Author to whom correspondence should be addressed; E-Mail: esteban@ciad.mx;

Tel.: +52-639-474-8400; Fax: +52-639-474-8704.

Academic Editor: Luca Sebastiani

Received: 15 April 2015 / Accepted: 10 June 2015 / Published: 23 June 2015

\begin{abstract}
Grafting favors the presence of bioactive compounds in the bell pepper, but many species and varieties have not yet been analyzed in this sense, including commonly grafted varieties. The aim of the present study is to characterize the content in $\beta$-carotenes, vitamin $C$, lycopene, total phenols, and the antioxidant activity of bell pepper (Capsicum annum L.) using the cultivar/rootstock combinations: Jeanette/Terrano (yellow), Sweet/Robusto (green), Fascinato/Robusto (red), Orangela/Terrano (orange), and Fascinato/Terrano (red). The plants were grown in a net-shading system and harvested on three sampling dates of the same crop cycle. The results show statistical differences $(p \leq 0.05)$ between cultivar/rootstock combinations and sampling dates for the content in bioactive compounds and antioxidant activity. Fascinato/Robusto presented the highest concentration of lycopene and total phenols as well as the greatest antioxidant activity of all cultivar/rootstock combinations evaluated. In addition, it was found that the best sampling time for the peppers to have the highest concentrations of bioactive compounds and antioxidant activity was September.
\end{abstract}

Keywords: bell pepper; bioactive compounds; grafting 


\section{Introduction}

Currently, people have interest in maintaining good health and an excellent body figure, therefore, they have become more careful in the food they choose to consume, looking for food with a high nutritional value, bioactive compounds and antioxidant capacity, such as fruits and vegetables.

Epidemiological studies have consistently demonstrated a positive relation between the consumption of fruits and vegetables and a reduction in the mortality rate due to heart disease, cancer, and other degenerative diseases, as well as aging. This is attributed to the fact that these foods are the main source of nutraceutical compounds, such as vitamins, minerals, and phenolic compounds, natural antioxidants, fiber, and other biotic compounds [1,2].

The bell pepper (Capsicum annum $\mathrm{L}$ ) is a fruit well known for its high content in bioactive compounds and strong antioxidant capacity and it is among the most popular of fresh vegetables worldwide due to its combination of color, flavor, and nutritional value [3]. The plant, native to North and South America, is most productive in warm, dry climates and is used both medicinally as well as a food in Africa and other countries of the world [4].

Currently, a broad number of varieties are available in the supermarkets, most of which change from a green color to yellow, orange, red, or purple when they are completely ripe. Green peppers are often harvested before they completely ripen, and the maturity stage can partly account for the content in phytonutrients and thus the consumption of antioxidants in the diet [5].

Fresh peppers have exceptionally high quantities of ascorbic acid and their attractive red color is due to several carotenoid pigments that include $\beta$-carotene with pro-vitamin A activity and oxygenated carotenoids such as capsantine, capsorubin, and cryptocapsin, which are exclusive to these fruits and have proven to be effective at scavenging free radicals [6]. Peppers also contain large quantities of neutral phenolic compounds or flavonoids called quercetin, luteolin, and capsaicinoids [7].The consumption of these bioactive compounds provide beneficial effects in human health due to their antioxidant properties, which protect against the oxidative damage to cells and thus prevent the development of common degenerative diseases such as cancer, cardiovascular diseases, cataracts, diabetes, Alzheimer's, and Parkinson's [3]. These chemical compounds also prevent the oxidation of essential fats within the cells of the brain that are considered necessary for its optimal functioning [8].

Due to the economic and nutritional importance of bell peppers, actually the use of grafting is increasing in this crop, the main applications have been to control nematodes, soil-borne diseases [9,10], and wilt caused by Phytophthora capsici [11-13]. In addition, grafting has been evaluated for its effect on the crop yield and morphological characteristics of the fruit [14], moreover, grafting favors the presence of certain phytochemical compounds and antioxidant activity, but many species and varieties still have not been analyzed in this sense, including commonly grafted varieties.

The aim of the present study is to characterize the content in bioactive compounds and antioxidant activity of different varieties of grafted bell pepper (Capsicum annum L.) harvested on three different sampling dates in the same crop cycle. 


\section{Experimental Section}

\subsection{Approach and Experimental Design}

For the experiment, the commercial varieties of bell pepper (Syngenta Seed, Houston, TX, USA) Jeanette, Sweet, Fascinato and Orangela were used as scions and were grafted from either Terrano or Robusto rootstock (Syngenta Seeds).

The fruits of grafted bell pepper were analyzed in order to determine the content in bioactive compounds and antioxidant activity. The pepper fruits were obtained from a commercial crop belonging to an agricultural company that exports this produce grown under net shading. In the experiment, the following bell pepper cultivar/rootstock combinations (Syngenta Seeds) were studied and used as treatments: (1) Jeanette/Terrano (yellow); (2) Sweet/Robusto (green); (3) Fascinato/Robusto (red); (4) Orangela/Terrano (orange); and (5) Fascinato/Terrano (red). The commercial rootstocks Terrano and Robusto were used due to their resistance to the wilt caused by the fungus Phytophthora capsici and to nematodes, in addition to their excellent affinity for the main pepper varieties to which they provide a vigorous root system and enable balanced vegetative development, favoring a healthy plant structure [15].

Rootstock seeds were sown in December 2012 and the varieties seeds were sown in January 2013. Commercial varieties were grafted 31 days after sowing. Thirty-seven days after the grafting, the plants were transplanted to beds under net shading. The average temperature was $32{ }^{\circ} \mathrm{C}$ and relative humidity of $52 \%$. The plants were grown in a loamy sandy-clayey soil $(57.36 \%$ sand, $12.08 \%$ silt, and $29.84 \%$ clay) with $1.68 \%$ organic matter and whose chemical characteristics are: $\mathrm{pH} 7.72$, electrical conductivity of $0.84 \mathrm{dS} / \mathrm{m}, 50.17 \mathrm{ppm}$ inorganic-N, $64.14 \mathrm{ppm}$ phosphorus and CIC of $32.5 \mathrm{me} / 100 \mathrm{~g}$.

The fertilization program in $\mathrm{kg}$ per hectare for a cycle of 240 days was applied with the following forms and rates: Fert $05-30\left(49.5 \mathrm{~mL} / \mathrm{m}^{2}\right)$; phosphonitrate $\left(34.3 \mathrm{~g} / \mathrm{m}^{2}\right)$; potassium sulfate $\left(25.2 \mathrm{~g} / \mathrm{m}^{2}\right)$; ammonium nitrate $\left(92.2 \mathrm{~g} / \mathrm{m}^{2}\right)$; calcium nitrate $(46.8 \mathrm{~mL} / \mathrm{m} 2)$; potassium nitrate $\left(26.3 \mathrm{~g} / \mathrm{m}^{2}\right)$; magnesium sulfate $\left(85.6 \mathrm{~g} / \mathrm{m}^{2}\right)$; urea $\left(0.8 \mathrm{~g} / \mathrm{m}^{2}\right)$ super $\mathrm{K}\left(14.2 \mathrm{~mL} / \mathrm{m}^{2}\right)$; flussing $8-24\left(33.5 \mathrm{~mL} / \mathrm{m}^{2}\right)$; supplemented with commercial fertilizers.

The fruits harvested were classified as commercial quality according to the standard México Calidad Suprema [16].

For this study, three samples were made in the same 2013 crop cycle, the first on 4 July, the second on 20 August, and the third on 17 September.

One lot from each treatment was evaluated and, from each lot, fruits were sampled from 10 plants, these being considered as the experimental unit. The fruits were cleaned and taken to the laboratory to measure the content in vitamin $\mathrm{C}$, total phenols, lycopene, $\beta$-carotene, and antioxidant capacity.

\subsection{Determination of Bioactive Compounds}

\subsubsection{Vitamin $\mathrm{C}$}

Vitamin C content was determined by HPLC as described by Doner and Hicks [17]. The analysis was done with fresh bell pepper. The pepper pulp was cut into small pieces and ground to mash using a kitchen blender. $10 \mathrm{~g}$ of bell pepper were then placed in $20 \mathrm{~mL}$ of an extraction mixture. Then, it was homogenized and filtered before being analyzed. The sample was injected into a Varian HPLC ProStar 
320 equipped with a UV-Vis detector (ProStar 210, Prostar Varian Inc., Walnut Greek, CA, USA). An amine column Varian of $10 \mathrm{~cm}$ and a $20 \mu \mathrm{L}$ injection loop were used. The analysis was done in triplicate.

The limit of detection and quantification of the analytical method used for vitamin $\mathrm{C}$ quantification were 1.3 and $3.9 \mu \mathrm{g} / \mathrm{mL}$, respectively. Linearity was determined between 0 and $250 \mu \mathrm{g} / \mathrm{mL}$, using a standard ascorbic acid (vitamin C) high purity reagent grade, calibrating in triplicate. A typical calibration curve obtained for vitamin $\mathrm{C}$ is illustrated in Figure 1.

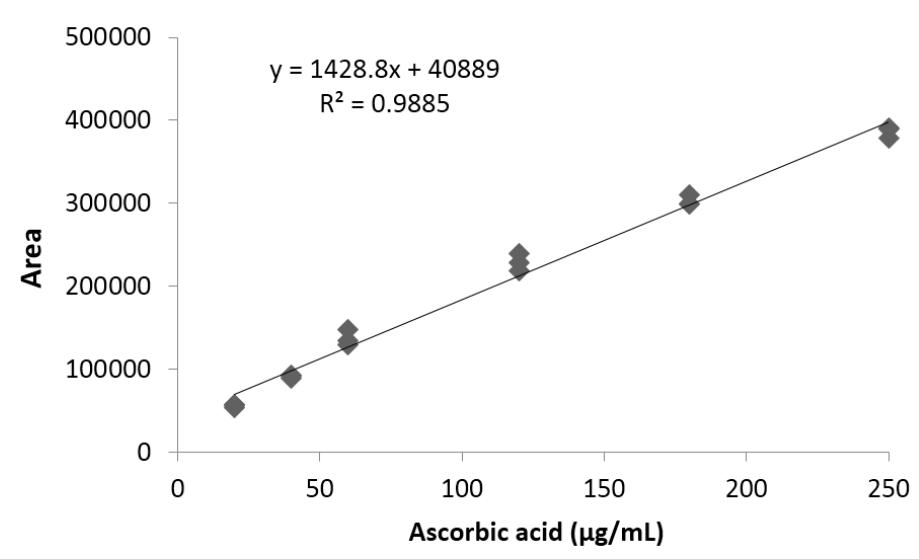

Figure 1. Representative standard curve obtained for vitamin C.

\subsubsection{Total Phenols}

The phenolic compounds of bell pepper were extracted with methanol. Total phenolic content was quantified by A765 with Folin-Ciocalteau reagent as described by Singleton and Rossi [18]. The limit of quantification of the analytical method used for total phenols quantification were 1.38 and $4.19 \mu \mathrm{g} / \mathrm{mL}$, respectively. The analysis was done in triplicate.

Linearity was determined between 0.02 and $0.1 \mu \mathrm{g} / \mathrm{mL}$, using a standard gallic acid high purity reagent grade, calibrated in triplicate. A typical calibration curve obtained for phenols is illustrated in Figure 2 .

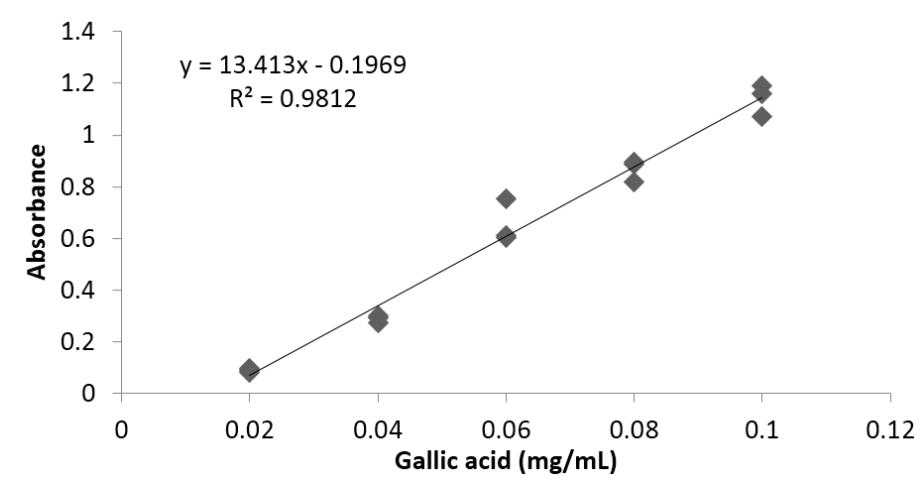

Figure 2. Representative standard curve obtained for total phenols. 


\subsubsection{Lycopene}

The lycopene content of bell pepper was determined according to the methodology reported by Cucu et al. [19]. Before analysis, the fresh bell pepper was milled, then, $1 \mathrm{~g}$ of pepper was mixed for $1 \mathrm{~min}$ with $20 \mathrm{~mL}$ of extraction buffer solution (hexane/acetone/ethanol 2:1:1) using an Ultra-Turrax on ice. The obtained mixture was filtered and transferred into a separatory funnel, $50 \mathrm{~mL}$ of saturated $\mathrm{NaCl}$ solution was added and the solution was mixed for $1 \mathrm{~min}$; the formation of two phases was allowed and once phases were well-separated, the aqueous phase was discarded and the hexane phase recovered and filtered over anhydrous $\mathrm{NaSO}_{4}(5 \mathrm{~g})$ which was rinsed twice with $2.5 \mathrm{~mL}$ of extraction buffer solution. The filtrate was dried under nitrogen and the resulting residue was redissolved in tetrahydrofuran (THF) with butylated hydroxytoluene (BHT), and triethylamide (TEA) at $0.05 \%$ to appropriate concentrations before being injected.

Identification and quantification of lycopene was carried out by HPLC, using a Varian ProStar 320 HPLC system with UV-Vis ProStar 210 detector (Prostar Varian Inc., Walnut Greek, CA, USA) at $472 \mathrm{~nm}$ and a reversed-phase $\mathrm{C} 18$ column of $10 \mathrm{~cm}$ with $\mathrm{MeOH} /$ isopropyl alcohol/THF (30:30:35) containing $250 \mathrm{ppm} \mathrm{BHT}$ and $0.05 \%$ TEA as the mobile phase. Flow rate was $1 \mathrm{~mL} / \mathrm{min}$, the temperature of the column was $35^{\circ} \mathrm{C}$, and the injection volume was $20 \mu \mathrm{L}$.

Standard solutions of lycopene were prepared and a calibration curve was obtained. Lycopene was identified by comparing the retention time with the reference standard and the quantification was done by external standard calibration based on peak area. The total lycopene content was quantified as the sum of the areas of the peaks of all the $\mathrm{E}$ and $\mathrm{Z}$ isomers, and based on the standard curve of all E-lycopene. The analysis was done in triplicate.

The limit of detection and limit of quantification of the analytical method used for lycopene quantification were 0.01 and $0.02 \mu \mathrm{g} / \mathrm{mL}$, respectively. Linearity was determined between 0.2 and $0.8 \mu \mathrm{g} / \mathrm{mL}$, using a standard lycopene high purity reagent grade, calibrating in triplicate. A typical calibration curve obtained for lycopene is illustrated in Figure 3.

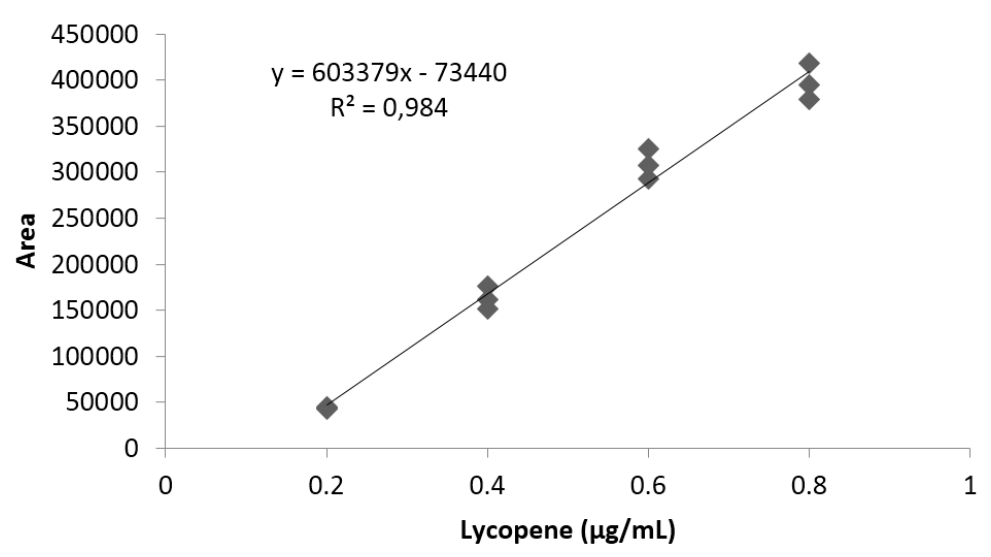

Figure 3. Representative standard curve obtained for lycopene.

\subsection{4. $\beta$-Carotene}

The methodology used was essentially that described by Mejia et al. [20]. For the analysis, only the pulp of fresh bell pepper was used. The peppers were chopped into fine pieces. Triplicate samples $(10 \mathrm{~g})$ 
were taken. The $10 \mathrm{~g}$ sample was combined with $1 \mathrm{~g}$ of magnesium carbonate, $10 \mathrm{~g}$ of sodium sulfate and $75 \mathrm{~mL}$ of tetrahydrofuran (THF) stabilized with $0.015 \%$ of butylated hydroxytoluene (BHT). The mixture obtained was homogenized twice at low speed for 2.5 a 3 min and kept on ice for 3-5 min to cool. The mixture was filtered and the residue was mixed with a second portion of $75 \mathrm{~mL}$ of THF and the extraction was repeated. The two filtrates were combined and the total filtrate was flash evaporated to a smaller volume using a Buchi rotary evaporator with temperature of $\leq 40{ }^{\circ} \mathrm{C}$. The reduced volume obtained was made up to a specific volume of $25 \mathrm{~mL}$ with THF to be analyzed by HPLC. Identification and quantification was carried out by HPLC, using a Varian ProStar 320 HPLC system with UV-Vis ProStar 210 detector and a C18-type column (Waters Nova-Pack (Waters Corp., Milford, MA, USA) of $3.9 \mathrm{~mm} \times 15 \mathrm{~cm}$. The solvent system was of acetonitrile $/ \mathrm{THF} / \mathrm{H}_{2} \mathrm{O}(85: 12.5: 2.5)$ pumped at a flow rate of $1 \mathrm{~mL} / \mathrm{min}$. All runs were at $24^{\circ} \mathrm{C}$ and detection at $460 \mathrm{~nm}$. HPLC peaks were identified using retention time comparison with trans- $\alpha$-carotene (Type V) and $\beta$-carotene (Type IV) standards and internal standards. The limit of detection and limit of quantification of the analytical method used for $\beta$-carotene quantification were 0.03 and $0.10 \mu \mathrm{g} / \mathrm{mL}$, respectively.

Linearity was determined between 1 and $20 \mu \mathrm{g} / \mathrm{mL}$, using a standard $\beta$-carotene high purity reagent grade, calibrated in triplicate. A typical calibration curve obtained for $\beta$-carotene is illustrated in Figure 4.

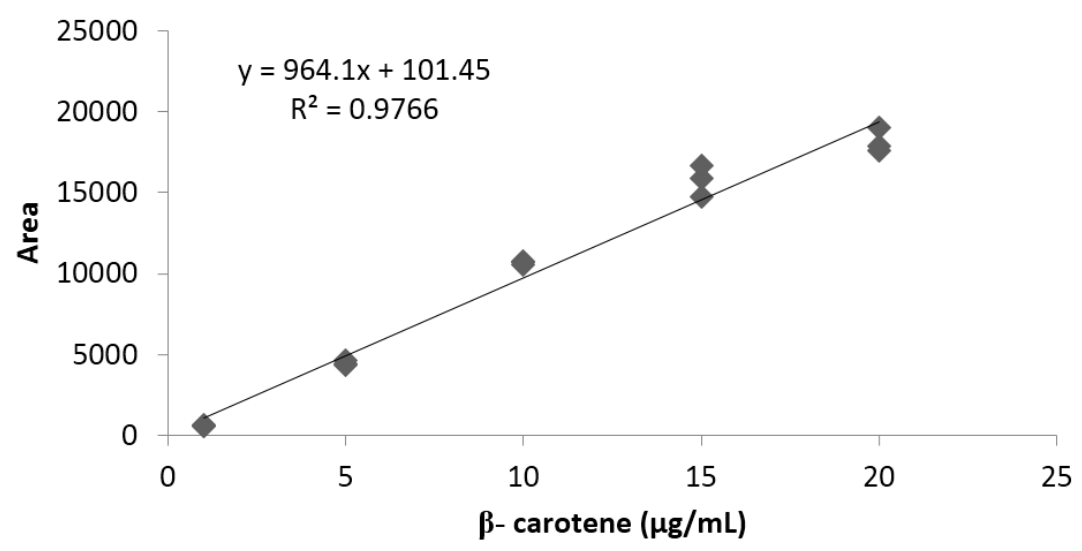

Figure 4. Representative standard curve obtained for $\beta$-carotene.

\subsubsection{Antioxidant Capacity}

The antioxidant capacity of bell pepper was determined following the technique reported by Zhuang et al. [21]. In order to obtain the antioxidant activity, an ethanolic extract was prepared, fresh peppers were ground and triplicate samples $(5 \mathrm{~g})$ were taken. The $5 \mathrm{~g}$ sample was extracted by stirring with $75 \mathrm{~mL} 80 \%$ ethanol at room temperature for $24 \mathrm{~h}$, and filtered. The filtrates were concentrated using a rotary vacuum evaporator at $40{ }^{\circ} \mathrm{C}$. The resultant extracts were used to determine the antioxidant activities. An aliquot of $0.4 \mathrm{~mL}$ of extract was taken and mixed with $2 \mathrm{~mL}$ of $0.1 \mathrm{mM}$ DPPH methanol solution. The mixture was kept at room temperature in the dark for $30 \mathrm{~min}$ and its absorbance was recorded at $517 \mathrm{~nm}$ in a microplate reader. 
The DPPH radical-scavenging activity was calculated according to Equation (1):

$$
\% \text { scavenging activity }=\left(\left(\mathrm{A}_{\text {control}}-\mathrm{A}_{\text {extract }}\right) / \mathrm{A}_{\text {control }}\right) \times 100
$$

where $\mathrm{A}_{\text {control }}=$ absorbance of the control, and Aextract $=$ absorbance of the extract.

The limit of detection and quantification of the analytical method used for antioxidant capacity determination were 0.6 and $1.85 \%$, respectively. Linearity was determined between 5 and $100 \mu \mathrm{g} / \mathrm{mL}$, using a standard ascorbic acid (vitamin $\mathrm{C}$ ) high purity reagent grade, calibrated in triplicate. A typical calibration curve obtained for DPPH is illustrated in Figure 5.

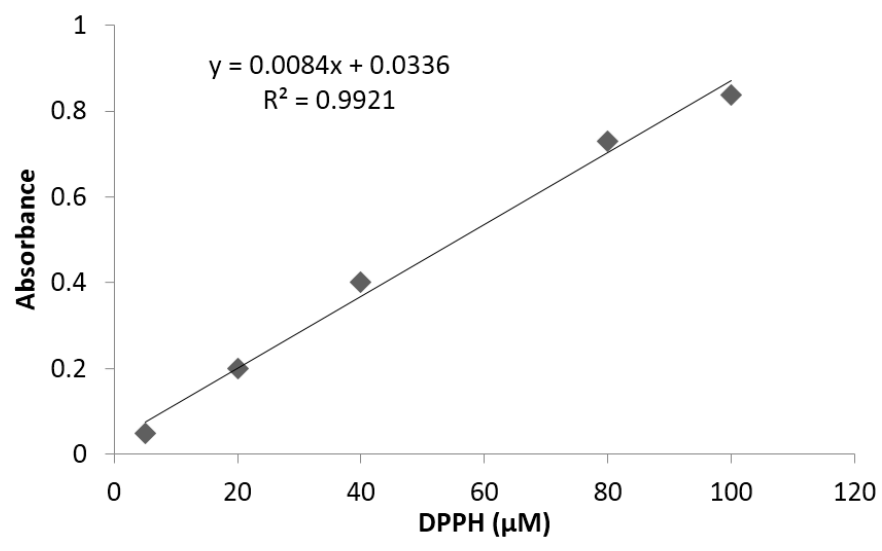

Figure 5. Representative standard curve obtained for antioxidant capacity.

\subsection{Statistical Analysis}

All analyses were performed in triplicated. The results were analyzed by analysis of variance, and a comparison of means was made by Tukey's test (SAS Inst. Inc., Cary, NC, USA). The means were accepted as significantly different at a 95\% confidence interval $(p \leq 0.05)$. In addition, a correlation analysis between the antioxidant capacity and bioactive compounds was conducted.

\section{Results and Discussion}

In the present work, the content in bioactive compounds and the antioxidant activity of varieties of grafted bell pepper was characterized. Figure 6 shows the morphology of grafted bell pepper studied, which correspond to the harvest of 3 July 2013.

\section{1. $\beta$-Carotenes}

Figure 7 shows the content in $\beta$-carotenes found in grafted bell pepper in three sampling dates. The statistical analysis showed differences $(p \leq 0.05)$ between cultivar/rootstock combinations and between sampling dates. On average, a greater content in $\beta$-carotenes was found in the peppers harvested on September. 


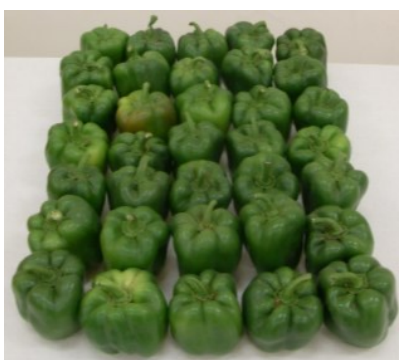

(a)

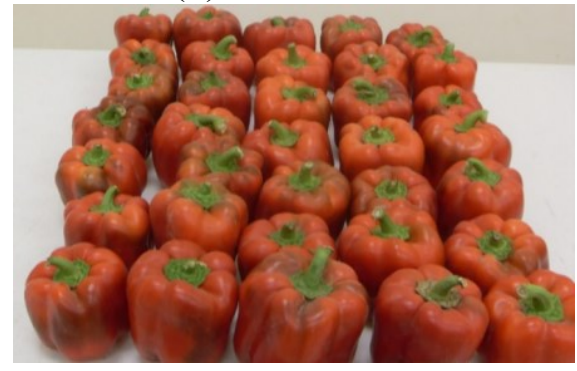

(d)

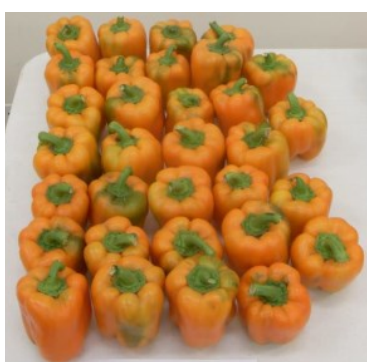

(b)

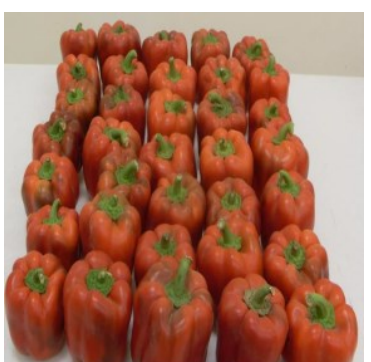

(c)

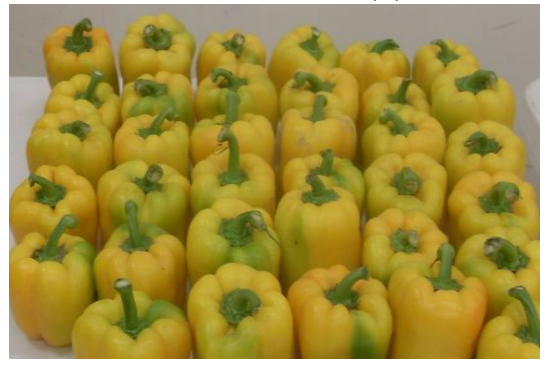

(e)

Figure 6. Samples of bell peppers harvested on 3 July 2013 used in the analysis: (a) Sweet/Robusto; (b) Orangela/Terrano; (c) Fascinato/Robusto; (d) Fascinato/Terrano; and (e) Jeanette/Terrano.

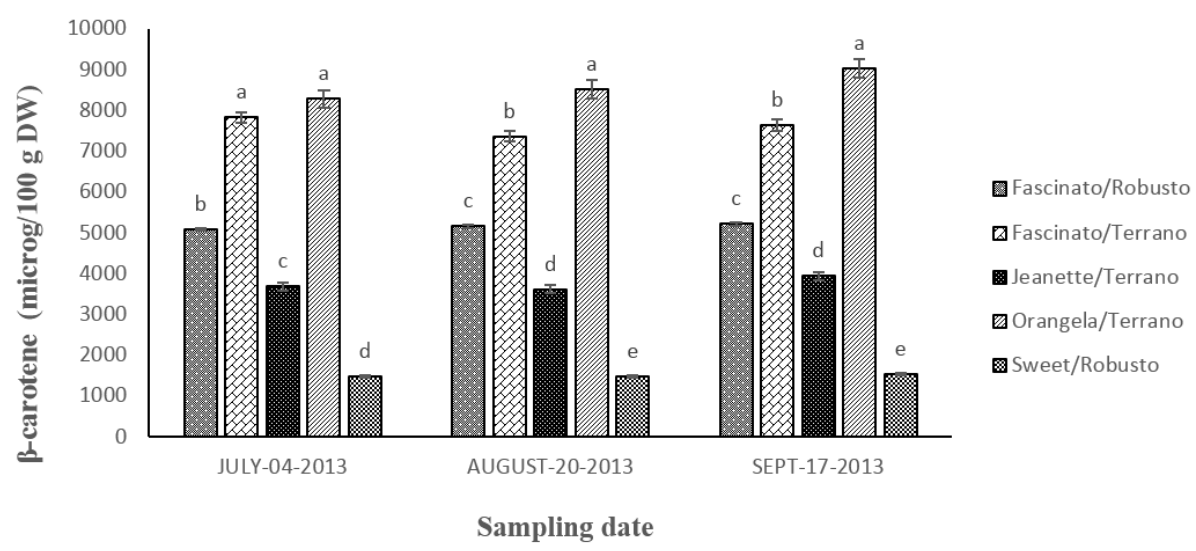

Figure 7. Content in $\beta$-carotenes in grafted bell pepper harvested on three different sampling dates. ${ }^{\mathrm{a}-\mathrm{e}}$ Different letters indicate statistical difference $(p \leq 0.05)$.

The concentration of this compound diminished as follows: Orangela/Terrano $>$ Fascinato/Terrano $>$ Fascinato/Robusto $>$ Jeanette/Terrano $>$ Sweet/Robusto.

Orangela/Terrano had a 5.8-fold greater content in $\beta$-carotenes than Sweet/Robusto, 2.3-fold more than Jeanette/Terrano, 1.7-fold more than Fascinato/Robusto, and 1.1-fold more than Fascinato/Terrano. Orangela/Terrano had an average content in $\beta$-carotenes of $8616.19 \mu \mathrm{g} / 100 \mathrm{~g}$ of dry weight. In all the samples, it presented the highest concentration of all the varieties evaluated. By contrast, Sweet/Robusto registered the lowest concentration, with an average of $1500.2 \mu \mathrm{g} / 100 \mathrm{~g}$ of dry weight.

The results found in this study were lower than reported by Hallmann and Rembialkowsca [22] in bell pepper varieties Roberta, Spartacus, and Berceo, cultivated both in the conventional system as well 
as organically in Poland but higher than those found in bell pepper varieties Mazurca, Parker, Torkel, Anupam, Ha-1195, Flamingo, Manhattan and Bomby evaluated by Deepa et al. [6].

Orangela/Terrano and Fascinato/Terrano presented a higher quantity of $\beta$-carotenes than in the peppers Serrano, Jalapeño, Poblano, and Caribú, while Fascinato/Robusto had a content similar to that found in Serrano pepper [20]. Carotenes are responsible for the yellow, red, and orange colors of fruits and vegetables, and offer beneficial health effects against different diseases such as cardiovascular disease, cancer, and other chronic diseases [23].

According to the results of the present study, the $\beta$-carotene content depends strongly on the variety. Thus, in agreement with Marín et al. [24], the concentration of this compound also depends strongly on the ripeness of the fruit, being higher in fully ripe fruit (red) than in immature fruits (green). This finding has been reported also by Deli et al. [25]. In another study, Blanco-Ríos et al. [3] found a higher concentration in peppers of the variety Simpaty (orange), followed by the variety Mazurca (red), then by Taranto (yellow), and finally the lowest content in the cultivar Orion (green), very similar results to those obtained in the present work.

Fascinato/Terrano registered a higher content of $\beta$-carotene than Fascinato/Robusto in all the sampling dates, indicating the greater compatibility with the rootstock Terrano than with Robusto. In agreement with Davis et al. [26], grafting affects the quality of vegetables and thus careful selection of the combination of scion/rootstock is vital to ensure high fruit quality. There are many reasons why the graft affects fruit quality; the most obvious is the incompatibility between the scions/rootstock, which induces sub-growth or overgrowth of the graft, resulting in a decrease in the flow of water and nutrients through the grafted binding causing wilt.

In agreement with Tundis et al. [27], the main reason for studying carotenoids in peppers is due to their bioactive properties, such as their provitamin A activity, antioxidant action, immune modulation and involvement in cell signaling. $\beta$-carotene, also, has been extensively investigated as a possible cancer preventive agent; however, the greatest benefits are obtained when these compounds are consumed along with other phytochemicals in whole foods, not from expensive dietary supplements [28].

\subsection{Vitamin $C$}

Figure 8 shows the content in vitamin $\mathrm{C}$ found in grafted bell pepper harvested on three sampling dates. The statistical analysis revealed differences $(p \leq 0.05)$ between cultivar/rootstock combinations but not between sampling dates $(p \geq 0.05)$.

On average, the vitamin $\mathrm{C}$ content in the cultivar/rootstocks combination analyzed declined in the following order: Sweet/Robusto $>$ Fascinato/Terrano $>$ Fascinto/Robusto $>$ Orangela/Terrano $>$ Jeanette/Terrano.

Sweet/Robusto had 1.3-fold higher content in vitamin C than Jeanette/Terrano, 1.2-fold more than Fascinato/Robusto; 1.16-fold more than Orangela/Terrano, and 1-fold more than Fascinato/Terrano.

Sweet/Robusto registered an average content in vitamin C of $165.56 \mathrm{mg} / 100 \mathrm{~g}$ dry weight, surpassing all the varieties evaluated in the sampling of July and September 2013, while in the August sampling the values were slightly lower than the concentration found in Fascinato/Terrano, although the difference was not statistically significant. 


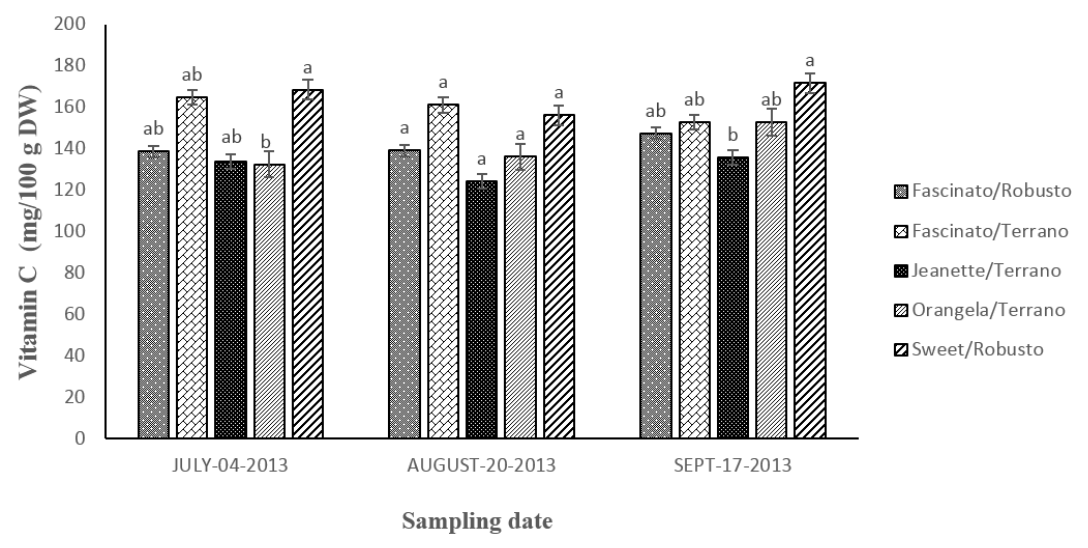

Figure 8. Vitamin $\mathrm{C}$ content in grafted bell peppers harvested on three different sampling dates. ${ }^{\mathrm{a}, \mathrm{b}}$ Different letters indicate statistical difference $(p \leq 0.05)$.

By contrast, Jeanette/Terrano had a lower vitamin C concentration, with an average content of $131.21 \mathrm{mg} / 100 \mathrm{~g}$ dry weight. These figures are lower than those found by Hallmann and Rembialkowska [22] in bell pepper cultivars Roberta, Spartacus and Berceo cultivated in conventional and organic system; and higher than those reported by Ghasemnezhad et al. [29] in the bell pepper genotypes Arian, Marona, Zorro, Y-43-09, and Y-43-07 under hydroponic cultivation.

Bell peppers are known to be an excellent source of vitamin C. Data from other studies has shown that the concentration of this vitamin increases with fruit ripeness [30,31]. In this respect, Navarro et al. [32] found that the amount of vitamin C incremented from the immature state of the fruit (green) to ripeness (red) with a higher concentration in the transition from green to red. According to Márkus et al. [33] vitamin $\mathrm{C}$ tended to increase at the onset of ripening, and later decreased with advanced ripening due to its antioxidant role, which increases with the increasing respiration rate in the climacteric fruits. Similar results have been found by Ghasemnezhad et al. [29] in the bell pepper cultivars Arian, Marona, Zorro, Y-43-09, and Y-43-07 grown hydroponically.

All the varieties analyzed in the present study are an excellent source of vitamin $C$, and exceeded the recommended daily dosage $(60 \mathrm{mg} / 100 \mathrm{~g})$ [34]. On average, Sweet/Robusto contributed with $26 \%$ of the recommended daily dosage (RDD) and Janette/Terrano with 218\%. These results are consistent with other studies reporting that bell peppers contribute from $25 \%$ to $461 \%$ of the RDD of vitamin C [31,35]. Howard et al. [31] reported that the variety Yellow Bell Pepper 47, immature and ripe, contributed with 190 and $225 \%$ of the RDD, respectively.

The identification of dietary sources of vitamin $\mathrm{C}$ is very important because humans do not have the capability to synthesize vitamin $\mathrm{C}$ due to a series of mutations of the gene encoding gulonolactone oxidase which catalyses the last enzymatic step in ascorbate synthesis [36]. Vitamin $C$ is an essential dietary nutrient for a variety of biological functions. Under physiological conditions, it is fundamental in the biosynthesis of collagen and serves in humans also as a co-factor in several important hydroxylation reactions, such as the biosynthesis of catecholamines, L-carnitine, cholesterol, amino acids, and some peptide hormones. In addition, vitamin $\mathrm{C}$ may reduce the incidence of most malignancies in humans and positive relationships have been shown between ascorbate supplement use and reduced incidence of Alzheimer's disease [37]. 
Much of the current focus on vitamin $\mathrm{C}$ has been on its role as an antioxidant. Antioxidant nutrients are thought to provide a buffer against cell damage that occurs during routine cell functions. Studies that examine the eating habits of large groups of people show that a high intake of vitamin $\mathrm{C}$ rich foods may reduce the risk of cancers of the mouth, pharynx, esophagus, stomach, lung, and pancreas. Furthermore, laboratory tests in animals have shown that vitamin $\mathrm{C}$ inhibits tumor growth and reduces the genetic damage caused by carcinogens. A potential role for vitamin $\mathrm{C}$ in the maintenance of eye health has also been found [38].

Fascinato/Terrano showed higher content of vitamin $\mathrm{C}$ than Fascinato/Robusto, showing better compatibility with the commercial rootstock Terrano than with Robusto. Previous studies have indicated that the rootstock Terrano improves the nutritional quality of bell pepper and increases the content of some bioactive compounds including vitamin C [39]. López-Marín et al. [40], however, found no differences in the vitamin $\mathrm{C}$ content of bell pepper variety Herminio ungrafted and grafted with Terrano. Gisbert et al. [12] found no differences, in the content of this vitamin in the pepper hybrids Almuden and Charlot grafted onto the rootstocks Charlot and Foc.

\subsection{Lycopenes}

Figure 9 shows the lycopene content in grafted bell peppers sampled on three different dates. The statistical analysis showed differences $(p \leq 0.05)$ between cultivar/rootstock combinations, sampling dates, and the interaction of "cultivar/rootstock combinations x sampling dates".

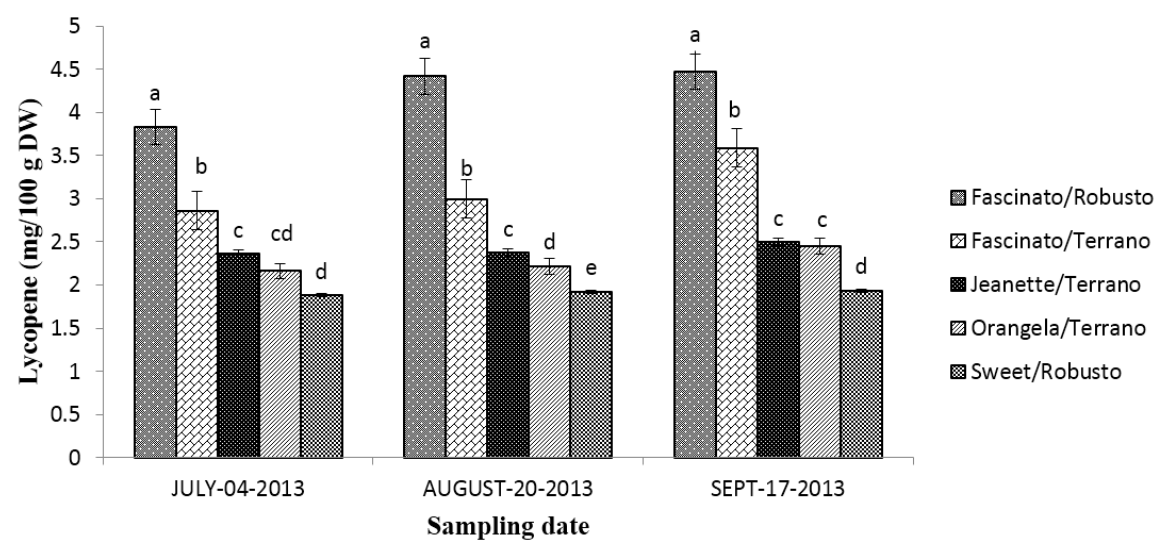

Figure 9. Lycopene content in grafted bell peppers harvested on three different sampling dates. ${ }^{\mathrm{a}-\mathrm{e}}$ Different letters indicate statistical difference $(p \leq 0.05)$.

The lycopene content in the cultivar/rootstock combinations diminished as follows: Fascinato/Robusto $>$ Fascinato/Terrano $>$ Jeanette/Terrano $>$ Orangela/Terrano $>$ Sweet/Robusto. This pattern held for all three sampling dates.

On average, a higher lycopene concentration was found in the bell peppers sampled in September $(p \leq 0.05)$ than in July or August; the difference between these latter two months was not statistically significant.

Fascinato/Robusto had an average lycopene concentration of $4.23 \mathrm{mg} / 100 \mathrm{~g}$ of dry weight, surpassing all the varieties evaluated, while the variety Sweet/Robusto had the lowest content, averaging 
$1.91 \mathrm{mg} / 100 \mathrm{~g}$ of dry weight. These results are lower than those reported by Navarro et al. [32] in turning and red bell peppers.

Tomato and its products are reportedly the main source of lycopene in the diet. At least $85 \%$ of the lycopene that we consume comes from these fruits, and the rest are obtained from other food sources such as apricots, pink grapefruit, watermelon, guava, and papaya [41].

Another important source of lycopene is the red bell pepper [42]. The lycopene values found in the present work were lower than reported by Vincovic-Vrcek et al. [43] in tomato varieties Herman, Efialto, and Maxifort grafted to the rootstock Tamaris cultivated in a greenhouse. These authors found no differences between grafted and ungrafted tomatoes. In this context, the bell peppers evaluated in the present work registered a lower lycopene content than watermelon varieties "Black Diamonds" and TriX313 in a state of complete ripeness, evaluated by Perkins-Veazie [44] and lower than Thai watermelon variety Jin-trarah studied by Charoensiri et al. [45].

According to Igbokwe et al. [4], red peppers have ninefold more lycopene than do green ones. In the present work, Fascinato/Robusto (red) contained twofold more lycopene than Sweet/Robusto (green). The differences in the lycopene levels depend on diverse factors that include variety, sampling method, preparation, method of determination, natural variation among fruits, fertilization, agroclimatic conditions, soil properties, solar radiation, geographic origin, and post-harvest conditions, among others [45].

Interest in carotenoids, particularly lycopene, has grown rapidly owing to studies suggesting a role in human health and disease. Lycopene is not toxic and has antioxidant, anti-inflammatory and chemotherapeutic effects in cardiovascular or neurodegenerative disease and in some cancer [46]. Many of the putative biologic effects and health benefits of lycopene are hypothesized to occur via protection against oxidative damage [47]. Lycopene appears to be the most efficient quencher of singlet oxygen and free radicals among the common carotenoids in vitro, this is due to its stereochemical properties. Because lycopene is not converted to vitamin A, it may be entirely available for other properties (e.g., antioxidation) and the lack of the b-ionone ring structure for lycopene may increase its antioxidant activity, this properties are quite different from those of other commonly consumed carotenoids, making it uniquely present in specific subcellular environments [48].

\subsection{Total Phenols}

Among the phytochemical compounds, polyphenols are of particular interest due to their property of scavenging free radicals in vivo. Epidemiological studies have shown a possible association between the consumption of polyphenols and a lower risk of coronary disease and cancer [49]. These benefits are due to its high antioxidant activity; antioxidants are hypothesized to play an important role in chronic disease prevention, because they might be able to prevent oxidative damage caused by reactive oxidant species to vital biomolecules such as DNA, lipids and proteins [50].

Bell peppers are rich in these types of compounds. Figure 10 presents the phenol content in grafted varieties of bell pepper sampled on three different dates. The statistical analysis indicated a significant difference $(p \leq 0.05)$ between cultivar/rootstock combinations and sampling dates. 


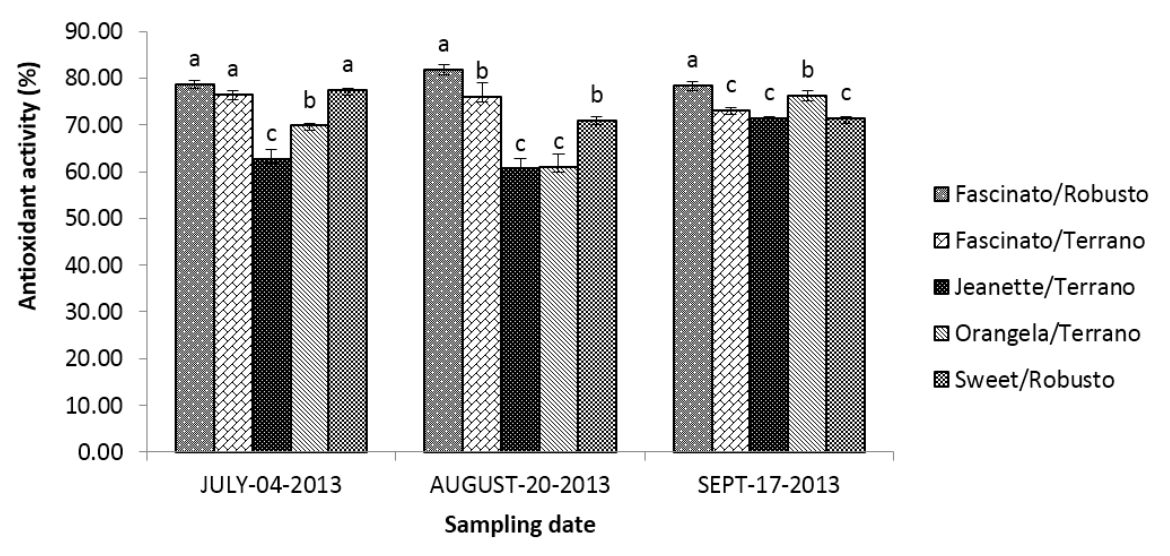

Figure 10. Total phenols content in grafted bell pepper varieties harvested on three different sampling dates. ${ }^{\mathrm{a}-\mathrm{c}}$ Different letters indicate statistical difference $(p \leq 0.05)$.

The average content in total phenols in cultivar/rootstock combinations diminished as follows: Fascinato/Robusto $>$ Jeanette/Terrano $>$ Fascinato/Terrano $>$ Orangela/Terrano $>$ Sweet/Robusto .

On average, the bell peppers harvested in September had higher $(p \leq 0.05)$ contents in total phenols than in July and August, the difference between these latter two months not being statistically significant.

Fascinato/Robusto had an average concentration in total phenols of $111.26 \mathrm{mg} / 100 \mathrm{~g}$ of dry weight, exceeding all cultivar/rootstock combinations evaluated, while Sweet/Robusto had the lowest content, averaging $70.39 \mathrm{mg} / 100 \mathrm{~g}$ of dry weight. These figures are higher than those given by Navarro et al. [32] in turning and red bell peppers and were lower than those given by Zhuang et al. [21] in red peppers; these authors reported that the total phenols increased as the peppers advanced in their state of ripeness, and thus the completely red fruits contained significantly higher quantities of this compound than the green fruits. Lee et al. [51] also reported an increase in the phenolic content of peppers with maturity. In another study, Hallman and Rembialkowska [22] found that the content in phenolic compounds is influenced also by the crop, as the organic system gives higher values than does the conventional one.

The content in total phenols in the present study depended on the variety and color of the bell pepper fruits. Higher contents in total phenols were found in bell peppers with color than in green ones, values being highest in red, followed by yellow, and then by orange. These results differ from the findings of Blanco-Ríos et al. [3], who found that the variety Orion (green) had the highest concentration in this compound, while no differences were detected between the varieties Mazurca (red), Simpaty (orange), and Taranto (yellow). In another study, Sun et al. [52] found greater phenolic content in red peppers, followed by orange, yellow, and finally green, as in the present study.

\subsection{Antioxidant Activity}

Among vegetables, bell peppers have been extremely popular for the abundance and types of antioxidants they contain. The phytochemical antioxidants that deserve special mention due to their strong capacity to scavenge free radicals are polyphenols, which are found in high quantities in bell peppers, whose levels vary strongly during growth and ripening [53].

Figure 11 presents the antioxidant activity of grafted bell pepper varieties at three different sampling dates. The statistical analysis showed differences $(p \leq 0.05)$ between cultivar/rootstock combinations, sampling dates and the interaction of "cultivar/rootstock combinations $x$ sampling dates". 


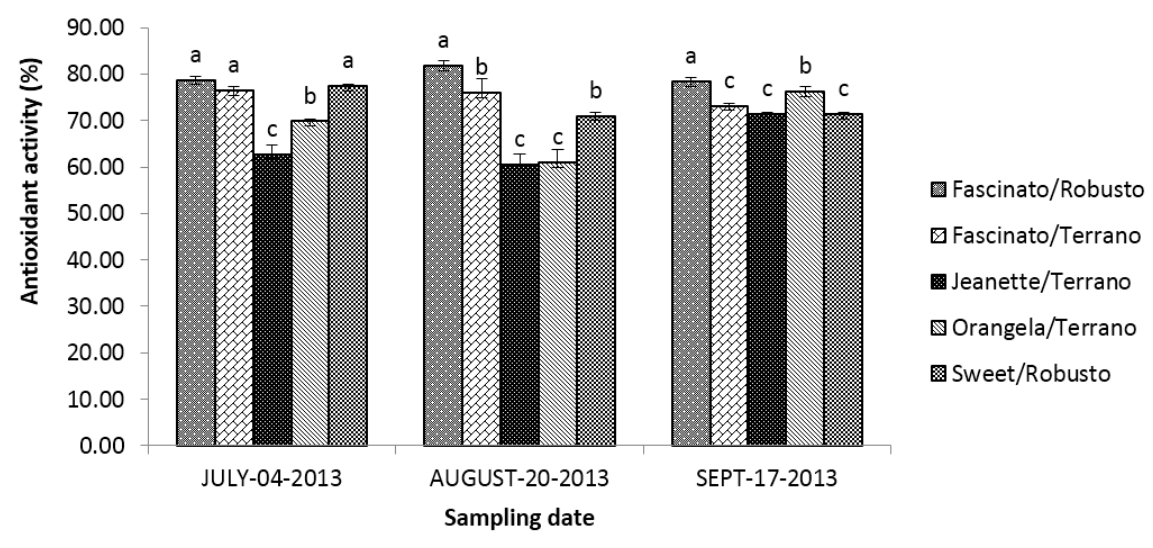

Figure 11. Antioxidant activity of grafted bell pepper varieties harvested in three different sampling dates. ${ }^{\mathrm{a}-\mathrm{d}}$ Different letters indicate statistical difference $(p \leq 0.05)$.

On average, the bell peppers harvested in September had higher $(p \leq 0.05)$ antioxidant activity than those sampled in July and August. Meanwhile, Deppa et al. [6] found no differences in the antioxidant activity of bell peppers between two years of harvest. In the present study, the average antioxidant activity of the cultivar/rootstock combinations diminished as follows: Fascinato/Robusto $>$ Fascinato/Terrano $>$ Sweet/Robusto $>$ Orangela/Terrano $>$ Jeanette/Terrano.

Thus, Fascinato/Robusto had the highest antioxidant activity of all cultivar/rootstock combinations evaluated, with an average of $79.65 \%$, while Jeanette/Terrano presented the lowest activity, with $64.90 \%$. These results are higher than those of Deepa et al. [6] in red bell peppers, which were found to have an antioxidant activity of $20 \%-71.7 \%$; for this range, the lowest concentration was presented by the variety Parker and the highest by the variety Flamingo. Previous studies showed that grafting improved the antioxidant activity of the variety Fascinato but not of Jeanette [39].

Phenolic compounds play a major role in the antioxidant activity in the bell peppers [52]. In the present study, Fascinato/Robusto presented the highest concentration of total phenols, as well as of lycopene in all cultivar/rootstock combinations evaluated, which coincides with a higher antioxidant activity.

The antioxidant activity of bell peppers can also be affected by ripeness. That is, the green fruits have a lower activity than the red ones, perhaps due to differences in the content in carotenoids, phenols, and flavonoids, which contribute significantly to the antioxidant activity and are found in red peppers but are scarce in green ones [52]. Howard et al. [30] reported higher antioxidant activity in ripe peppers of the variety Yellow Bell than in the immature ones (42.75\% and $66.9 \%$, respectively).

In the present study, the antioxidant activity was significantly affected by the cultivar/rootstock combinations and color. On average, the red bell peppers showed higher activity, followed by green, then orange, and finally yellow, although this depended primarily on the sampling date. The results were similar to those of Blanco-Ríos et al. [3], who found higher antioxidant activity in the red peppers (variety Mazurca), followed by green ones (Orion), then yellow ones (Taranto), and finally by orange ones (Simpaty). 


\subsection{Correlations}

The antioxidant activity of bell peppers can be attributed also to the content in vitamin C, carotenoids, and capsaicinoids, and therefore it is important to analyze the correlation between the antioxidant activity and the bioactive compounds of bell peppers due to the influence of other soluble compounds in addition to polyphenols, which could affect the total antioxidant capacity [54].

In the present study, the results revealed that in general in all the grafted varieties there was a correlation $(p \leq 0.05)$ between antioxidant activity and the lycopene and vitamin $\mathrm{C}$ concentration. In Sweet/Robusto the relation with lycopene was inverse $(r=-0.78)$. Jeanette/Terrano was the only cultivar/rootstock combination in which the antioxidant activity was correlated with lycopene, $\beta$-carotenes and total phenols; in all cases, the correlation was direct $(r=0.85, r=0.81$ and $r=0.69$ respectively). Meanwhile, no correlationsa $(p \geq 0.05)$ was found in Fascinato/Robusto, Orangela/Terrano and Fascinato/Terrano. Zhuang et al. [21] found a correlation between the antioxidant activity and the total phenols in bell pepper varieties. Similary, Medina-Juárez et al. [55] reported a close correlation between total phenols and antioxidant activity in bells peppers harvested in Zamora, Sonora, México $(r=0.91)$. While, Segura et al. [49] did not found correlation between total phenolic compounds and antioxidant capacity in Chiltepin and Habanero peppers, which may indicate that antioxidant capacity could be affected by the presence of phytochemicals such as carotenoids. Hwang et al. [56] reported a positive correlation between ascorbic acid, total phenols and antioxidant activity of cooked peppers. Many reports indicate correlation between antioxidant activity and phenolic compounds, of various food samples, for example, Yao et al. [57] reported a significant positive correlation between the antioxidant activity and the contents of total flavonoids and total phenols in celery. Campos et al. [58] found high correlations between antioxidant activities and total phenolic contents in mashua and oca tubers. It is well known that phenolic compounds exert antioxidant activity in biological systems. To estimate the inhibitory capacity of these compounds against reactive oxygen species, data correlating antioxidant activity and phenolic concentration are commonly reported [59].

\section{Conclusions}

The results of the present study reveal differences in the content of bioactive compounds and antioxidant activity among the grafted varieties of bell pepper. Fascinato/Robusto presented the highest concentrations of lycopenes and total phenols as well as the greatest antioxidant activity of all/cultivar/rootstock combinations evaluated. Meanwhile, Sweet/Robusto had the highest content in vitamin $\mathrm{C}$ and Orangela Terrano in $\beta$-carotenes. Furthermore, the best sampling date to have the highest content in bioactive compounds and strongest antioxidant activity proved to be in September. On the other hand, Fascinato/Terrano was a good source of bioactive compounds and antioxidant activity, as it was consistently cultivar/rootstock combination with the second-highest quantity of these compounds.

\section{Acknowledgments}

We appreciate the support of project key 195770 PROINNOVA-CONACYT, and we thank the agricultural company LOS ALAMOS by all facilities provided to carry out the project. 


\section{Author Contributions}

Esteban Sanchez has designed the study and Celia Chávez-Mendoza analyzed the data and prepared the manuscript, whereas Ezequiel Muñoz-Marquez, Juan Pedro Sida-Arreola, and Maria Antonia Flores-Cordova conducted the experiments. All authors read and approved the final manuscript.

\section{Conflicts of Interest}

The authors declare no conflict of interest.

\section{References}

1. Bayili, R.G.; Abdoul-Latif, F.; Kone, O.H.; Diao, M.; Bassole I.H.N.; Dicko, M.H. Phenolic compounds and antioxidant activities in some fruits and vegetables from Burkina Faso. Afr. J. Biotechnol. 2011, 10, 13543-13547.

2. Kaur, Ch.; Kapoor, H.C. Antioxidants in fruits and vegetables the millennium's health. Int. J. Food Sci. Technol. 2001, 36, 703-725.

3. Blanco-Ríos, A.K.; Medina-Juarez, L.A.; González-Aguilar, G.A.; Gamez-Meza, N. Antioxidant activity of the phenolic and oily fractions of different sweet bell peppers. J. Mex. Chem. Soc. 2013, 57, 137-143.

4. Igbokwe, G.E.; Aniakor, G.C.; Anagonye, C.O. Determination of $\beta$-Carotene \& Vitamin C content of Fresh Green Pepper (Capsicum annnum), Fresh Red Pepper (Capsicum annum) and Fresh Tomatoes (Solanum lycopersicum) Fruits. Bioscientist 2013, 1, 89-93.

5. Shotorbani, N.; Jamei, R.; Heidari, R. Antioxidant activities of two sweet pepper Capsicum annuum L. varieties phenolics extracts and the effects of thermal treatment. Avicenna J. Phytomed. 2013, 3, 25-34.

6. Deepa, N.; Kaur, Ch.; Singh, B.; Kapoor, H.C. Antioxidant activity in some red sweet pepper cultivars. J. Food Comp. Anal. 2006, 19, 572-578.

7. Hasler, C.M. Functional foods: Their role in disease prevention and health. Food Technol. 1998, 52, 63-69.

8. Oboh, G.; Rocha, T.B.J. Distribution and antioxidant activity of polyphenols in ripe and unripe tree pepper (Capsicum pubescens). J. Food Biochem. 2007, 31, 456-473.

9. Kokalis-Burelle, N.; Bausher, M.G.; Rosskopf, E.N. Greenhouse evaluation of Capsicum rootstocks for management of Meloidogyne incognita on grafted bell pepper. Nematropica 2009, 39, 121-132.

10. Oka, Y.; Offenbach, R.; Pivonia, S. Pepper rootstock graft compatibility and response to Meloidogyne javanica and M. incognita. J. Nematol. 2004, 32, 137-141.

11. Gilardi. G.; Baudino M.; Moizio, M.; Pugliese, M.; Garibaldi, A.; Gullino, M.L. Integrated management of Phytopthora capsici on bell pepper by combining grafting and compost treatment. Crop Prot. 2013, 53, 13-19.

12. Gisbert, C.; Sánchez-Torres, P.; Raigón, M.D.; Nuez, F. Phytophthora capsici resistance evaluation in pepper hybrids: Agronomic performance and fruit quality of pepper grafted plants. J. Food Agric. Environ. 2010, 8, 116-121. 
13. Jang. Y.; Yang, E.; Cho, M.; Um, Y.; Ko, K.; Chun, C. Effect of grafting on growth and incidence of Phytopthora Blight and bacterial wilt of pepper (Capsicum annuum L). Hortic. Environ. Biotechnol. 2012, 53, 9-19.

14. Leal-Fernández, C.; Godoy-Hernández, H.; Núñez-Colín, C.A.; Anaya-Lopez, J.I.; Villalobos-Reyes, S.; Castellanos, J.Z. Morphological response and fruit yield of sweet pepper (Capsicum annuum L) grafted onto different commercial rootstocks. Biol. Agric. Hortic. 2013, 29, $1-11$.

15. Syngenta. Catálogo de Semillas Hortícolas. Available online: http://www3.syngenta.com/country/ es/sp/productos/semillas/horticolas/paginas/horticolas.aspx (accessed on 20 August 2014).

16. SAGARPA. Secretaría de Agricultura, Ganadería, Desarrollo Rural, Pesca y Alimentación. Pliego de Condiciones Para el uso de la Marca Oficial, México Calidad Suprema en Pimiento Morrón. Available online: http://www.mexicocalidadsuprema.org/assets/galeria/PC_022_2005_Pimiento.pdf (accessed on 20 June 2014).

17. Doner, L.W.; Hicks, K.B. High-performance liquid chromatographic separation of ascorbic acid, erythorbic acid, dehydroascorbic acid, dehydroerythorbic acid, diketogulonic acid, and diketogluconic acid. Anal. Biochem. 1981, 115, 225-230.

18. Singleton, V.L.; Rosi, J.A. Colorimetric of total phenolics with phosphomolybdic-phosphotungstic acid reagents. Am. J. Enol. Vitic. 1965, 16, 144-158.

19. Cucu, T.; Huvaere, K.; van den Bergh, M.A.; Vinkx, C.; Van Loco, J. A simple and fast HPLC method to determine lycopene in foods. Food Anal. Method. 2012, 5, 1221-1228.

20. Mejia, L.A.; Hudson, E.; Gonzalez de Mejia, E.; Vazquez, F. Carotenoid content and vitamin A activity of some common cultivars of Mexican peppers (Capsicum annuum) as determined by HPLC. J. Food Sci. 1988, 53, 1448-1451.

21. Zhuang, Y.; Chen, L.; Sun, L.; Cao, J. Bioactive characteristics and antioxidant activities of nine peppers. J. Funct. Foods 2012, 4, 331-338.

22. Hallmann, E.; Rembialkowska, E. Characterization of antioxidant compounds in sweet bell pepper (Capsicum annuum L) under organic and conventional growing systems. J. Sci. Food Agric. 2012, 92, 2409-2415.

23. Rao, A.V.; Rao L.G. Carotenoids and human health. Pharmacol. Res. 2007, 55, 207-216.

24. Marín, A.; Ferreres, F.; Tomás-Barberán, F.A.; Gil, M.I. Characterization and quantitation of antioxidant constituents of sweet pepper (Capsicum annuum L). J. Agric. Food Chem. 2004, 52, 3861-3869.

25. Deli, J.; Molnar, P.; Toth, G. carotenoid composition in the fruits of red paprika (Capsicum annuum var. lycopersiciforme rubrum) during ripening; biosynthesis of carotenoids in red paprika. J. Agric. Food Chem. 2001, 49, 1517-1523.

26. Davis, A.R.; Perkins-Veazie, P.; Sakata, Y.; Lopez-Galarza, S.; Maroto, J.V.; Lee, S.G.; Huh, Y.C.; Sun, Z.; Miguel, A.; King, S.R.; et al. Cucurbit grafting. Crit. Rev. Plant. Sci. 2008, 72, $50-74$.

27. Tundis, R.; Loizzo, R.M.; Menichini, F.; Bonesi, M.; Conorti, F.; Statti, G.; de Luca, D.; de Cindio, B.; Menichini, F. Comparative study on the chemical composition antioxidants properties and hypoglycemic activities of two Capsicum annum L. Cultivars (Acuminatum small and Cerasiferum). Plant. Food Hum. Nutr. 2011, 66, 261-269. 
28. Hai, L.R. Potential synergy of phytochemicals in cancer prevention: Mechanism of action. J Nutr. Suppl. 2004, 134, 3479S-3485S.

29. Ghasemnezhad, M.; Sherafati, M.; Payvast, G.A. Variation in phenolic compounds, ascorbic acid and antioxidant activity of five coloured bell pepper (Capsicum annum) fruits at two different harvest times. J. Funct. Foods 2011, 3, 44-49.

30. Howard, L.R.; Smith, R.T.; Wagner, A.B.; Villalon, B.; Burns, E.E. Provitamin A and ascorbic acid content of fresh pepper cultivars (Capsicum annuum) and processed jalapenos. J. Food Sci. 1994, 59, 362-365.

31. Osuna-Garcia, J.A.; Wall, M.M.; Waddell, C.A. Endogenous levels of tocopherols and ascorbic acid during fruit ripening of New Mexican-type chile (Capsicum annuum L). J. Agric. Food Chem. 1998, 46, 5093-5096.

32. Navarro, J.M.; Flores, P.; Garrido, C.; Martinez, V. Changes in the contents of antioxidant compounds in pepper fruits at different ripening stages, as affected by salinity. Food Chem. 2006, 96, 66-73.

33. Márkus, F.; Dood, H.G.; Kapitány, J.; Biacs. P.A. Change in the carotenoid and antioxidant content of spice red pepper (paprika) as a function of ripening and some technological factors. J. Agric. Food Chem. 1999, 47, 100-107.

34. Levine, M.; Conry-Cantilena, C.; Wang, Y.; Welch, W.R.; Washko, W.P.; Dhariwal, R.K.; Park, B.J.; Lazarev, A.; gaumlich, F.J.; King, J. Vitamin C pharmacokinetics in healthy volunteers: Evidence for a recommended dietary allowance. Proc. Natl. Acad. Sci. USA 1996, 93, 3704-3709.

35. Simmone, A.H.; Simmone, E.H.; Eitenmiller, R.R.; Mills, H.A.; Green, N.R. Ascorbic acid and provitamin A contents in some unusually colored bell peppers. J. Food Compos. Anal. 1997, 10, 299-311.

36. Nishikimi, M.; Koshizaka, T.; Ozawa, T.; Yagi, K. Occurrence in humans and guinea pigs of the gene related to their missing enzyme L-gulono-gamma-lactone oxidase. Arch. Biochem. Biophys. 1988, 267, 842-846.

37. Grosso, G.; Bei, R.; Mistretta, A.; Marventano, S.; Calabrese, G.; Masuelli, L.; Giganti, M.G.; Modesti, A.; Galvano, F.; Gazzolo, D. Effects of vitamin C on health: A review of evidence. Front. Biosci. 2013, 18. 1017-1029.

38. Levine, M.; Rumsey, S.C.; Daruwala, R.; Park, J.B.; Wang, Y. Criteria and recommendations for vitamin C intake. JAMA 1999, 281, 1415-1423.

39. Chávez-Mendoza, C.; Sánchez, E.; Carvajal-Millán, E.; Muñoz-Márquez, E.; Guevara-Aguilar, A. Characterization of the nutraceutical quality and antioxidant activity in bell pepper in response to grafting. Molecules 2013, 18, 15689-15703.

40. Lopez Marin, J.; Gonzalez, A.; Pérez-Alfocea, F.; Egea-Gilabert, C.; Fernandez, J.A. Grafting is an efficient alternative to shading screen to alleviate thermal stress in greenhouse-grown sweet pepper. Sci. Hortic. 2013, 149, 39-46.

41. Nour, V.; Trandafir, I.; Ionica, E.M. Antioxidant compounds, mineral content and antioxidant activity of several tomato cultivars grown in southwestern Romania. Not. Bot. Hortic. Agrobot. 2013, 41, 136-142. 
42. Fadupin G.T.; Osadola O.T.; Atinmo T. Lycopene Content of Selected Tomato Based Products, Fruits and Vegetables Consumed In South Western Nigeria. Afr. J. Biomed. Res. 2012, 15, 187-191.

43. Vinkovic-Vrcek, I.; Samobor, V.; Bojic, M.; Medic-Saric, M.; Vukobratovic, M.; Erhatic, R.; Horvat, D.; Matotan, Z. The effect of grafting on the antioxidant properties of tomato (Solanum lycopersicum L). Span. J. Agric. Res. 2011, 9, 844-851.

44. Perkins-Veazie, O. Carotenoids in watermelon and mango. Acta Hortic. 2007, 746, 259-264.

45. Charoensiri, R.; Kongkachuichai, R.; Suknicom, S.; Sungpuag, P. Beta-carotene, lycopene, and alpha-tocopherol contents of selected Thai fruits. Food Chem. 2009, 113, 202-207.

46. Cruz, B.R.M.; González, G.J.; Sánchez, C.P. Propiedades funcionales y beneficios para la salud del licopeno. Nutr. Hosp. 2013, 28, 6-15.

47. Clinton, S.K. Lycopene: Chemistry, Biology, and Implications for Human Health and Disease. Nutr. Rev. 1998, 56, 35-51.

48. Giovannucci, E. Tomatoes, Tomato-Based Products, Lycopene, and Cancer: Review of the Epidemiologic Literature. J. Natl. Cancer. Inst. 1999, 91, 317-331.

49. Segura, C.M.R.; Ramírez, G.K.; Moguel, O.Y.; David Betancur, A.D. Polyphenols, ascorbic acid and carotenoids contents and antioxidant properties of habanero pepper (Capsicum chinense) Fruit. Food Nutr. Sci. 2013, 4, 47-54.

50. Hollman C.H.P. Evidence for health benefits of plant phenols: Local or systemic effects. J. Sci. Food Agric. 2001, 81, 842-852.

51. Lee, Y.; Howard, L.R.; Villalon, B. Flavonoids and antioxidant activity of fresh pepper (Capsicum annuum) cultivars. J. Food Sci. 1995, 60, 473-476.

52. Sun, T.; Xu, Z.; Wu, C.T.; Janes, M.; Prinyawiwatkul, W.; No, H.K. Antioxidant activities of different colored sweet bell peppers (Capsicum annuum L). J. Food Sci. 2007, 72, S98-S102.

53. Nadeem, M.; Anjum, M.F.; Khan, R.M.; Saeed, M.; Riaz, A. Antioxidant potential of bell pepper (Capsicum annum L.) a review. Pak. J. Food Sci. 2011, 21, 45-51.

54. Hervert-Hernandez, D.; Sayago-Ayerdi, S.G.; Goñi, I. Bioactive compounds of four hot pepper varieties (Capsicum annuum L), antioxidant capacity, and intestinal bioaccessibility. J. Agric. Food Chem. 2010, 58, 3399-3406.

55. Medina-Juárez, L.A.; Molina-Quijada, D.M.A.; del Toro, S.C.L.; González-Aguilar, G.A. Gámez-Meza, N. Antioxidant activity of peppers (Capsicum annuum L) extracts and characterization of their phenolic constituents. Interciencia 2012, 37, 588-593.

56. Hwang, I.G.; Shin, Y.J.; Lee, S.; Lee, J.; Yoo, S.M. Effects of different cooking methods on the antioxidant properties of red pepper (Capsicum annuum L.). Prev. Nutr. Food Sci. 2012, 17, 286-292.

57. Yao, Y.; Sang, W.; Zhou, M.; Ren, G. Phenolic composition and antioxidant activities of 11 celery cultivars. J. Food Sci. 2010, 75, C9-C13.

58. Campos, D.; Noratto, G.; Chirinos, R.; Arbizu, C.; Roca, W.; Cisneros-Zevallos, L. Antioxidant capacity and secondary metabolites in four species of Andean tuber crops: Native potato (Solanum sp.), mashua (Tropaeolum tuberosum Ruiz \& Pavón), oca (Oxalis tuberosa Molina) and ulluco (Ullucus tuberosus Caldas). J. Sci. Food Agric. 2006, 86, 1481-1488. 
59. Jacobo-Velazquez, D.A.; Cisneros-Zevallos, L. Correlations of antioxidant activity against phenolic content revisited: A new approach in data analysis for food and medicinal plants. J. Food Sci. 2009, 74, R107-R113.

(C) 2015 by the authors; licensee MDPI, Basel, Switzerland. This article is an open access article distributed under the terms and conditions of the Creative Commons Attribution license (http://creativecommons.org/licenses/by/4.0/). 